\title{
Differences in Improving Students' Communication Ability and Learning Independence Through Problem Based Learning Models and Guided Discovery
}

\author{
Dessy Meylinda ${ }^{1}$, Elmanani Simamora $^{2}$, Mukhtar $^{3}$ \\ 1, 2,3 Mathematics Education, Postgraduate, Medan State University, \\ Williem Iskandandar Pasar V Medan Estate Street, Medan, Indonesia \\ meylindadessy@gmail.com
}

\begin{abstract}
This study aims to analyze the differences in the improvement of students 'mathematical communication skills and learning independence through problem-based learning models and guided discovery as well as the interaction between learning models and early mathematics skills on students' mathematical communication skills and learning independence. The research population was all class VIII students of MTs Negeri 3 Labuhanbatu Utara in the odd semester of the 2019/2020 academic year, totaling 230 students in six classes. The research sample was taken randomly, namely class VIII-F and VIII-A. The first experimental class gets a problem-based learning model, and the second experimental class gets a guided discovery learning model. The instrument consists of a test of mathematical communication skills and a questionnaire for students' learning independence. Data analysis used a combination of study of covariance (ANCOVA) and N-Gain. The results showed differences in the increase in mathematical communication skills and learning independence of students who received a better problem-based learning model than those given guided discovery learning. There was no interaction between the learning model and the early mathematical ability on communication skills and student learning independence.
\end{abstract}

Keywords: Mathematical Communication, Student Learning Independence, Problem Based Learning, Guided Discovery, Early Mathematical Ability

\begin{abstract}
Abstrak
Penelitian ini bertujuan untuk menganalisis perbedaan peningkatan kemampuan komunikasi matematis siswa dan kemandirian belajar melalui model pembelajaran berbasis masalah dan penemuan terbimbing serta interaksi antara model pembelajaran dan kemampuan awal matematika terhadap kemampuan komunikasi matematis siswa dan kemandirian belajar. Dimana populasi penelitian ini adalah seluruh siswa kelas VIII MTs Negeri 3 Labuhanbatu Utara semester ganjil tahun pelajaran 2019/2020 yang berjumlah 230 siswa dalam enam kelas. Sampel penelitian diambil secara acak yaitu kelas VIII-F dan VIII-A. Kelas eksperimen pertama mendapatkan model pembelajaran berbasis masalah, dan kelas eksperimen kedua mendapatkan model pembelajaran penemuan terbimbing. Instrumen terdiri dari tes kemampuan komunikasi matematis dan angket kemandirian belajar siswa. Analisis data menggunakan analisis kovarian (ANCOVA) dan N-Gain. Hasil penelitian menunjukkan bahwa terdapat perbedaan peningkatan kemampuan komunikasi matematis dan kemandirian belajar siswa yang mendapat model pembelajaran berbasis masalah lebih baik daripada yang diberi pembelajaran penemuan terbimbing dan tidak ada interaksi antara model pembelajaran dengan kemampuan matematika awal terhadap kemampuan komunikasi. matematis dan kemandirian belajar siswa.
\end{abstract}

Kata kunci: Kemampuan Komunikasi, Kemandirian Belajar Siswa, Pembelajaran Berbasis Masalah, Penemuan terbimbing, Kemampuan Awal Siswa

Copyright (c) 2021 Dessy Meylinda

$\triangle$ Corresponding author: Dessy Meylinda

Email Address: meylindadessy@ gmail.com (Williem Iskandar Pasar V, Medan Estate Street, Medan, Indonesia) Received 12 Januari 2021, Accepted 25 Januari 2021, Published 08 Februari 2021

\section{INTRODUCTION}

Education is one of the fundamental aspects of life (Kulsum, Hidayat, Wijaya, \& Kumala, 2019; Tan, Zou, Wijaya, Suci, \& Dewi, 2020; Wijaya, Ying, Cunhua, \& Zulfah, 2020). Through education, human development aims to develop their potential and abilities to achieve particular competencies that support life in the future (Dini, Wijaya, \& Sugandi, 2018). Educational sources 
come from academic and non-academic environments. School is an academic environment for obtaining formal education. Regulation of the Ministry of Education and Culture of the Republic of Indonesia Number 58 of 2014 regulates Indonesia's formal mathematics education based on the curriculum. Mathematics is a language of symbols that symbolizes a series of meanings from statements. Saragih \& Napitupulu (2015) Expectations of learning mathematics for students can apply mathematics in their daily lives and connect with other sciences.

The National Council of Teachers of Mathematics (2003) states that the objectives of learning mathematics are as follows: 1) learning for problem-solving, 2) learning for reasoning and proof, 3) learning for the ability to associate mathematical ideas, 4) learning for mathematical communication, 5) studied for mathematical representations. Based on what NCTM stated above, we concluded that students' abilities to master mathematics are mathematical communication skills. Communication skills are one of the mathematical powers besides problem-solving, reasoning, connection, and representation. Ansari (2016) revealed two reasons that communication skills are considered essential and need development for students. First, communication is a means of sharing ideas precisely and accurately in solving problems or drawing conclusions. Second, the use of communication in mathematics as a means of interaction between students and communication between teachers and students. Dewey (1964) In this case, communication (Communication) is one of the mathematical power (Mathematical Power) in addition to problem solving, reasoning, connection and representation.

The field's reality shows that learning mathematics in Indonesia in mathematical communication is still low (Aminah, Wijaya, \& Yuspriyati, 2018; Andini, Mulyani, Wijaya, \& Supriyati, 2018). The preliminary study of the research conducted a preliminary ability test to determine students' mathematical communication abilities (Baroody ,1993). We have found that the students' written mathematical communication skills were still low. The test results showed that the students' mathematical communication skills were still low, and the class's classical completeness percentage was only 22.8\%. Similarly, Mulbar's statement (2008) that teachers evaluate the achievement of learning outcomes only emphasizes cognitive goals without paying attention to the process, especially those related to students' mathematical communication skills. Teachers often forget efforts to introduce communication in solving math problems to students. Lack of student learning independence is one of the causes of the low mathematical communication skills of students. Adhiawati (2014) argues that mathematics education has two primary goals: formal goals, which emphasize the structuring of children's reasoning, and the formation of children's personalities and material goals that emphasize the application of mathematics and problem-solving abilities.

In mathematics, teachers have to create a learning atmosphere that can encourage students to be more independent. Thus students who have independent learning will be more active and responsible in every learning activity they do and can more easily understand the mathematical concepts they are studying. Widarto \&Widodo (2012) Apart from independent learning, which is considered necessary, 
students' initial mathematics ability is also one of the prerequisites for participating in learning to carry out the learning process well. The abilities a person gains from training during his lifetime and what he brings to face a new experience.

Zimmerman (1990) stated that initial ability is an initial prerequisite for recognizing changes. Early math skills are a prerequisite for learning new material. An essential prerequisite for constructing knowledge and individual learning outcomes is the initial proficiency of students. Effendi (2012) Students can construct new knowledge based on the initial abilities and connect the various knowledge they already have to construct new knowledge. Several factors affect students' low quality in learning mathematics, one of which is learning that is not optimal. Most teachers in teaching and learning still pay less attention to students' thinking skills (Wijaya, Ying, Chotimah, et al., 2020), the models used are also less varied, and as a result, independent learning students become challenging to grow. Problem-based learning is an alternative to improving students' mathematical communication skills and learning independence. Problem-based learning is a student-centered one, no longer teacher-centered (Minarni, 2013). Sanjaya (2018) Problem-based learning has advantages in its application because students work on real problems where students can compile their knowledge, improve higher-order thinking skills, and develop independence and self-confidence (Zhang, Zhou, \& Wijaya, 2020). One of teaching-learning approach that should be implemented in the school is Problem-based learning. It can be said that Problem-based learning is an instructional (and curricular) learner-centered approach that empowers the learners to conduct research, integrate theory and practice, and apply knowledge and skills to develop a viable solution to a defined problem (Minarni, Napitupulu \& Husein, 2016).

Apart from problem-based learning, another learning that is creative, innovative and effective is guided discovery learning. In guided discovery, the teacher encourages students to make guesses, intuition, and experiment. Barrows, Howard S., \& Tamblyn, Robyn M. (1980) Knowledge acquired through discovery does some good. First, it is enduring and easier to remember when compared to knowledge learned in other ways. Second, discovery learning outcomes have a better transfer effect than other learning outcomes. Third, thoroughly discovery learning enhances students' ability to think freely. Dewey (1964) Based on the characteristics of student-centered guided discovery and has several advantages by applying the guided discovery approach which is predicted to improve students' mathematical communication skills and learning independence.

Kuhlthau (2007) Through guesswork and intuition, it is hoped that students will not just accept the concepts, principles, or procedures that have been made in mathematics teaching and learning activities, but students are more emphasized on the aspects of finding and finding mathematical concepts, principles, or procedures. To produce a discovery, students must be able to connect the mathematical ideas they have. To connect these ideas, they can communicate the idea through pictures, graphics, symbols, or words to become simpler and easier to understand. Bishop (1988) Familiarize students with learning discovery, indirectly also accustom students to represent 
information, data, or knowledge to produce findings. Looking at the problem's background, the researchers raised problems related to mathematical communication skills and student learning independence with problem-based learning models and guided discovery.

\section{METHOD}

This research is quasi-experimental. In this quasi-experimental research, control over all external variables that affect the course of the research in this study cannot be controlled, the grouping of experimental class 1 and experiment 2 is carried out based on previously formed groups or existing groups. This study's treatment was mathematics learning with Problem Based Learning and Guided Invention Based Learning, while the observed variables were mathematical communication skills and students' mathematical learning independence. Russeffendi (2005) suggests that in quasi-experimental research, the subjects' group is not random, but researchers accept the subject's conditions as they are.

This research was conducted at MTs Negeri 3 Labuhan Batu Utara class VIII for the Academic Year 2020/2021 with the implementation schedule coordinated with school activities, precisely in October 2020. The reason for choosing the research location to be carried out was because similar research had never been carried out at the school.

The sampling process refers to the population size. The group sampling technique was carried out randomly (random sampling). The random selection stage is possible because based on information from the principal and teacher, the simple random sampling technique is the simplest sampling technique because the sampling of members from the population is taken randomly without considering the existing strata in the population Sugiyono (2012). the distribution of students in each class is heterogeneous evenly. So that the sample selection in this study is numbering each class on paper and then doing a lottery. Class VIII at MTs Negeri 3 Labuhan Batu Utara consists of 5 classes. The sample chosen was class VIII-F as the experimental class- 1 consisting of 30 students and class VIII-A as the experimental class-2 consisting of 30 students. This research consists of the preparation stage, implementation stage, analysis stage and report writing. The flow of this research can be summarized in Figure 1 below.

In this study, obtaining data from the initial mathematics ability results, pre-test and post-test of mathematical communication skills consists of 5 questions and a student learning independence questionnaire consists of 25 questions. Then do the analysis with the ANCOVA test. Accompanying variables lead to the ANCOVA test in this study where the independent variables are difficult but can be measured together with the dependent variable. Kadir (2015) argued that the essence of Ancova is the use of a linear regression model to eliminate the effect of the unexamined variables which are commonly called covariates on the criterion variable. The mathematical model for covariate analysis is expressed as follows:

$$
Y_{i j}=\mu+\tau_{i}+\beta\left(X_{i j}-\bar{X}_{t}\right)+\epsilon_{i j}
$$

$\mathrm{i}=1,2, \ldots, \ldots, \mathrm{n} ; \mathrm{j}=1,2, \ldots, \ldots, \mathrm{m}$ 
Information:

$\mathrm{Y}_{\mathrm{ij}} \quad$ : The posttest score of the jth student produced in learning to $\mathrm{i}$

M : The average score of students'posttest

$\tau_{\mathrm{i}} \quad$ : The influence of learning $\mathrm{i}$ to learning outcomes

B : Regression coefficient indicating dependence $Y_{\mathrm{ij}}$ for $X_{i j}$

$\overline{\mathrm{X}}_{\mathrm{t}} \quad$ : Pretest mean score

$X_{i j} \quad:$ The measurement of the $\mathrm{j}$ th student pretest that was generated in the I th learning related to $\mathrm{Y}_{\mathrm{ij}}$

$\epsilon_{\mathrm{ij}} \quad$ : error component that arises in students-j from learning-i

Before using the ANCOVA test, the data need to do a prerequisite test, namely: (1) Normality Test; (2) Homogeneity Test; (3) Regression Model Linearity Test; and (4) Test Alignment of Regression Lines.

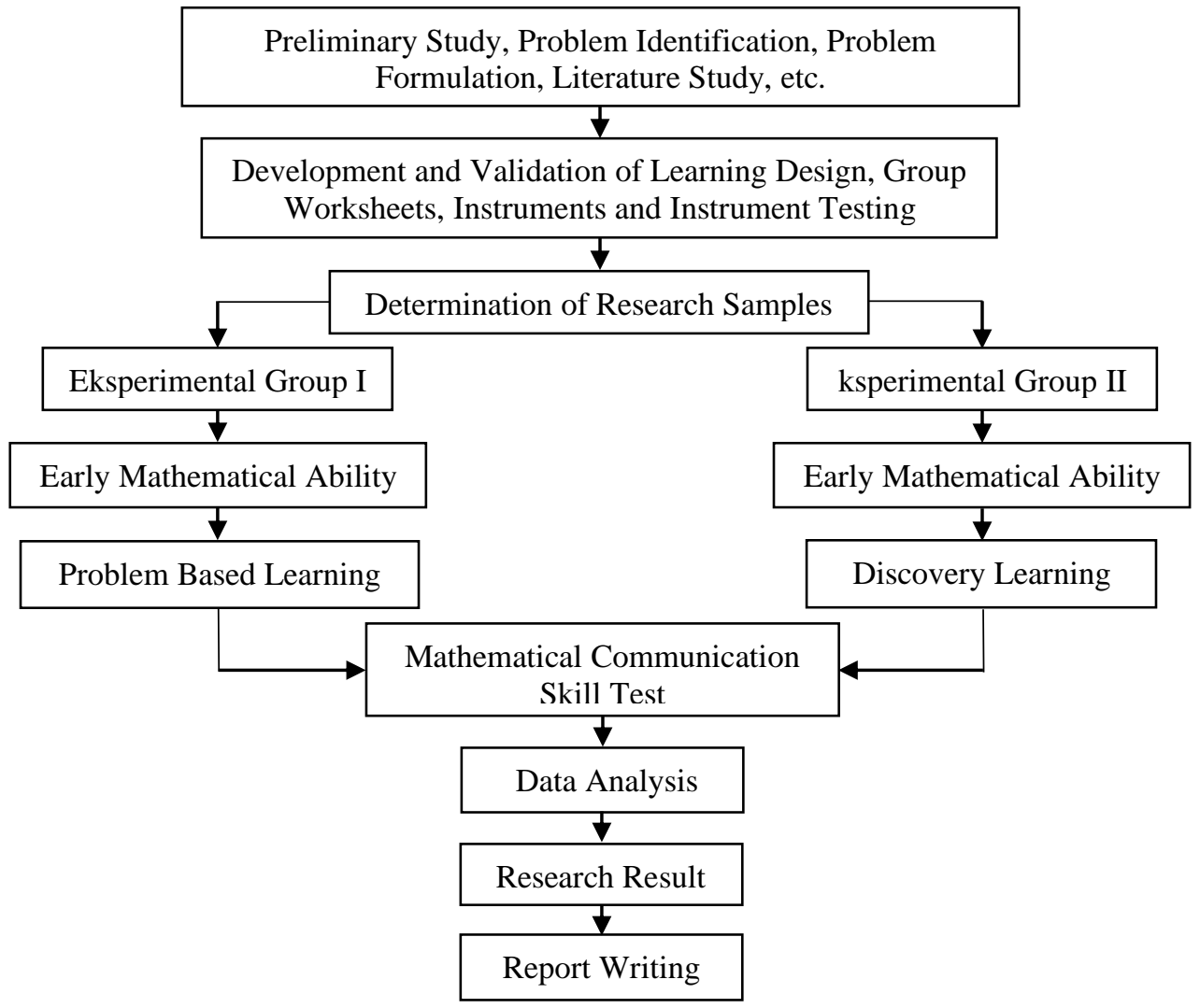

Figure 1. Research Procedure

\section{RESULT AND DISCUSSION}

From the research results obtained, it will discuss its relationship with the objectives that have been set. The discussion is conducted based on several factors, namely communication skills, student 
learning independence and early math skills.

\section{Communication skills and student learning independence.}

In general, the implementation of learning goes well, so it affects students' mathematical communication skills and learning independence. This learning factor is one of the things that affects the improvement of students' mathematical communication skills and learning independence. Where the stage in problem-based learning contributes to the improvement of mathematical communication skills and student learning independence.

Based on the study results, the average normalized gain score of students' mathematical communication abilities who were given problem-based learning was 0.54 higher than students who were given guided discovery by 0.28 . This study's results indicate that the average increase in the communication skills of students taught with problem-based learning is higher than students taught with guided discovery.

Furthermore, research to show that the independent learning of students based on the initial test (questionnaire I) and the final test (questionnaire II) in the experimental class I obtained an average NGain of 0.37 and the experimental class II was 0.16 . The increase can be seen from the difference between the average questionnaire II and the average questionnaire I with an ideal score. This shows that there is an increase in student learning independence in the experimental class I. The statistical test results for the hypothesis are known from the ANCOVA results obtained from the probability value (sig) of 0.000 which is smaller than the probability level (sig) of 0.05 . In this study the increase in mathematical communication skills of students taught with guided discovery learning was higher than students taught with guided discovery.

Then to see if there are differences in the improvement of students' mathematical communication skills who are given the problem-based learning model and the guided discovery learning model.The full ANCOVA test results can be seen in table 1 below:

Table 1. ANCOVA Results Students' Mathematical Communication Ability Tests of Between-Subjects Effects (Dependent Variable: PostTest_PBMPT)

\begin{tabular}{|l|r|r|r|r|r|}
\hline Source & $\begin{array}{c}\text { Type III Sum } \\
\text { of Squares }\end{array}$ & Df & Mean Square & F & Sig. \\
\hline Corrected Model & $2341.397 \mathrm{a}$ & 2 & 1170.698 & 14.890 & .000 \\
Intercept & 2247.738 & 1 & 2247.738 & 28.589 & .000 \\
PreTest_PBMPT & 1071.797 & 1 & 1071.797 & 13.632 & .000 \\
Learning & 1288.191 & 1 & 1288.191 & 16.384 & .000 \\
Error & 4481.537 & 57 & 78.623 & & \\
Total & 373112.000 & 60 & & & \\
Corrected Total & 6822.933 & 59 & & & \\
\hline
\end{tabular}

a. R Squared $=.343$ (Adjusted R Squared $=.320$ )

Table 1. Shows the learning model factor is obtained p-value $=0,000<0,05$ means that $\mathrm{H}_{0}$ is rejected and with the $\mathrm{N}$-Gain value for experimental class I 0,54 category medium and experimental 
class II 0.28 category low. Furthermore, because the two regressions for the two classes are homogeneous and the constant equality of the linear regression line for the communication ability of the experimental class I is 26.607 greater than the linear regression line equation for Experiment II class, which is 19.898, geometrically the regression line for the experimental class I is above the class regression line. experiment II. This indicates a significant difference, and in the above hypothesis there is a difference in the heights of the two regression lines that are influenced by the regression constant. The height of the regression line describes student learning outcomes, namely when $\mathrm{X}=0$ then the regression equation for communication skills in experimental class $\mathrm{I}$ is obtained $\mathrm{Y}=26.607$ and the regression equation for Experiment class II Y $=19,898$ so it can be concluded that there is a difference in the increase in students' mathematical communication skills given the model. Problembased learning and in the guided discovery learning model after controlling students 'initial abilities where the increase in students' mathematical communication skills in the application of problembased learning models is better than the application of guided discovery learning models.

Then to see if there is a difference in student learning independence who is given a problembased learning model and a guided discovery learning model.The full ANCOVA test results can be seen in table 2 below:

Table 2. ANCOVA Results for Student Learning Independence

Tests of Between-Subjects Effects (Dependent Variable: Questionnaire_PostTest_PBMPT)

\begin{tabular}{|l|r|r|r|r|rr|}
\hline Source & \multicolumn{1}{|c|}{$\begin{array}{c}\text { Type III Sum } \\
\text { of Squares }\end{array}$} & Df & Mean Square & \multicolumn{1}{|c|}{ F } & Sig. \\
\hline Correcte & $1507.754^{\mathrm{a}}$ & 2 & 753.877 & 35.423 & & .000 \\
d Model & 82.420 & 1 & 82.420 & 3.873 & & .054 \\
Intercept & 555.737 & 1 & 555.737 & 26.113 & .000 \\
PreTest_- & 1326.062 & 1 & 1326.062 & 62.308 & & .000 \\
PMBPT & 1213.096 & 57 & 21.282 & & & \\
Learning & 60 & & & & \\
Error & 276707.000 & 59 & & & & \\
Total & Correcte & 2720.850 & 59 & & \\
d Total & & & & \\
\hline
\end{tabular}

a. $\mathrm{R}$ Squared $=.554$ (Adjusted R Squared $=.539)$

Table 2. Shows the learning model factor is obtained $\mathrm{p}$-value $=0,000<0,05$. means that $\mathrm{H}_{0}$ rejected and with the $\mathrm{N}$-Gain value of the experimental class I 0.37 in the medium category and the experimental class II 0.16 the low category. Furthermore, because the two regressions for the two classes are homogeneous and the constant equality of the linear regression line for the communication ability of the experimental class I is 30.594 greater than the linear regression line equation for Experiment class II, which is 10.638, geometrically the regression line for experimental class I is above the class regression line experiment II. This indicates a significant difference, and in the above 
hypothesis there is a difference in the heights of the two regression lines that are influenced by the regression constant. The height of the regression line describes student learning outcomes, namely when $\mathrm{X}=0$, the regression equation for learning independence for experimental class I is obtained $\mathrm{Y}$ $=30.594$ and the regression equation for Experiment class II Y $=10.638$ so that it can be concluded that there is a difference in the increase in student learning independence given the learning model problem-based and in the guided discovery learning model after controlling the students' initial abilities where the increase in student learning independence in the application of problem-based learning models is better than the application of guided discovery learning models.

The research results in the table above indicate that the improvement of communication skills and learning independence of students who learn with problem-based learning is higher in improving communication skills and learning independence of students who get guided discovery. This is because problem based learning has advantages over guided discovery. The application of problembased learning models in mathematics learning requires students to learn to find concepts that train thinking skills and analyze and manipulate information. By applying this model students can find and use various sources of information and ideas to improve understanding of a problem, topic or problem. Students support learning to a large extent through their own active interaction with concepts and principles.

Based on the principle of problem-based learning, the learning process begins by presenting real-world or contextual problems that aim to develop students' higher thinking, critical thinking, and solve the problems presented. This given problem is used to bind students to learning curiosity. Questions are given to students before they learn the concept or material regarding the problem. Problem-based learning also helps students process ready-made information in their minds to organize their own knowledge of the social world and its surroundings. This learning is suitable for developing basic and complex knowledge. In addition, this learning model is also suitable for improving student learning activities, both individually and in groups. In this lesson, the teacher guides and provides minimal instruction to students in solving problems. Teachers are required to be able to create a conducive learning atmosphere to help students practice in the process of given questions.

This is a major finding in students who get problem-based learning and students who get guided discovery. Students who get guided discovery learning will require students to learn to discover the concepts being learned, practice thinking skills, and manipulate information. By applying this model students can find and use various sources of information and ideas to improve understanding of a problem, topic or problem. Students support learning to a large extent through their own active interaction with concepts and principles. Arends (2008) also suggests that an independent person will take action and behave in a certain way.

This discovery presents a learning atmosphere that makes teachers dominate learning activities. Guided discovery makes the teacher a learning resource for students, the teacher plays a major role in the process of transferring knowledge to students, the teacher explains the knowledge presented, asks 
students to provide the explanation given by the teacher calmly. If there are several things related to students, the question and answer process occurs between students and teachers. After giving the material, the teacher provides training on what has been learned. The series of activities carried out by students on guided discovery will make students inactive in learning. Students only listen to all the things served by the teacher, listen to then accept the teacher's explanation. This will result in students not really understanding certain knowledge. The knowledge provided is only rote memorization for students. From the results of the data analysis above, it can be concluded that there are differences in the increase in mathematical communication skills and learning independence of students who get better problem-based learning than those who get guided discovery learning.

\section{Students' Early Mathematical Abilities}

This study's early math skills test was used to determine students' early math skills groups based on high, medium, and low early math skills groups. Early math skills grouping is also used to answer problems related to mathematical communication skills and students' learning independence who are given problem-based learning and guided discovery. In obtaining new learning, students must use the knowledge and experience to participate in further learning. The things that have been learned will be used to deal with, solve new things and communicate them. For this reason, so that students can achieve good learning outcomes, they are first given an initial mathematical ability test so that they can find out what knowledge, skills, and competencies the students already have when they are going to take part in teaching.

So, the height or breadth of students 'knowledge, information, experience and abilities that will be used to learn the next lesson is expected to increase the possibility of improving students' mathematical communication skills and learning independence.

\section{The Interaction Between Learning and Students 'Initial Ability on the Improvement of Students' Mathematical Communication Ability}

The interaction referred to in this study is the interaction between learning factors and students 'initial abilities towards improving students' communication skills. In the initial ability of students, students are grouped according to high, medium and low abilities. The researchers' findings indicated that there was no interaction between the learning model and the students 'early mathematics abilities on students' mathematical communication skills.

These results can be seen from the results of research where the average normalized gain of communication skills based on problem-based learning for the high (0.83), medium (0.54) and low (0.19) groups. While guided discovery the average gain is normalized for the high (0.73), medium (0.47) and low (0.14) groups. In this case, the students 'initial mathematics ability in problem-based learning with the high initial mathematics ability category had a smaller increase than the students' initial mathematics ability in the high category guided discovery. 
To see if there is an interaction between the learning model and the students 'initial mathematics ability to the students' mathematical communication skills. The full ANCOVA test results can be seen in table 3 below.

Table 3. ANCOVA Analysis Results for the Interaction Between KAM and Learning Models on Mathematical Communication Skills

Tests of Between-Subjects Effects

Dependent Variable: PostTest_PBMPT

\begin{tabular}{|l|r|r|r|r|r|}
\hline Source & $\begin{array}{c}\text { Type III Sum } \\
\text { of Squares }\end{array}$ & df & Mean Square & \multicolumn{1}{|c|}{ F } & \multicolumn{1}{c|}{ Sig. } \\
\hline Corrected Model & $2565.672^{\mathrm{a}}$ & 6 & 427.612 & 5.323 & .000 \\
Intercept & 2425.023 & 1 & 2425.023 & 30.190 & .000 \\
PreTest_PBMPT & 866.453 & 1 & 866.453 & 10.787 & .002 \\
\hline Learning & 1200.541 & 1 & 1200.541 & 14.946 & .000 \\
KAM & 159.211 & 2 & 79.605 & .991 & .378 \\
Learning* early & 47.252 & 2 & 23.626 & .294 & .746 \\
mathematical & & & & & \\
abilities & 4257.262 & 53 & 80.326 & & \\
Error & 373112.000 & 60 & & & \\
Total & 6822.933 & 59 & & & \\
Corrected Total & & & & \\
\hline
\end{tabular}

a. $\mathrm{R}$ Squared $=.376$ (Adjusted R Squared $=.305$ )

obtained $F_{\text {count }}$ factor of learning * early mathematical abilities of 0.294 while $F_{\text {table }(1,51)}=3,179$ which means $F_{\text {count }}<F_{\text {table }}$ dan p-value of 0,378 which means greater than 0.05 so that $\mathrm{H}_{0}$ is accepted so that it can be concluded that there is no interaction between the learning model and students' initial mathematical abilities on students' mathematical communication skills after controlling for students' initial abilities. Graphically this interaction can be seen in Figure 2 below.

Furthermore, the research results on communication skills in the interaction between learning factors and students' initial mathematics ability factors can be seen from the ANCOVA test results obtained from the probability value (sig) of 0.378 which is greater than the probability level (sig) 0.05. So it can be concluded that in this study there is no interaction between the learning model and students 'initial mathematical abilities on students' mathematical communication skills.

Theoretically, the interaction occurs as a result of the teacher's learning during the teaching and learning process, which can develop students' abilities in mathematics, not because of the different initial abilities of students. This acceptance could have been due to the grouping of students' initial abilities that did not describe their true abilities, inaccurate sample selection, relatively short research time and there were some students who had permission to go home and did not attend school due to illness, resulting in differences in increased communication skills. in each initial ability (high, medium and low) using problem-based learning models and guided discovery. This is supported by 
research conducted by Marbun (2019), in which the study used a problem-based learning model and the result was that there was no interaction between learning and the initial mathematics ability to increase students' mathematical understanding abilities.

Estimated Marginal Means of Post test_PBMPT

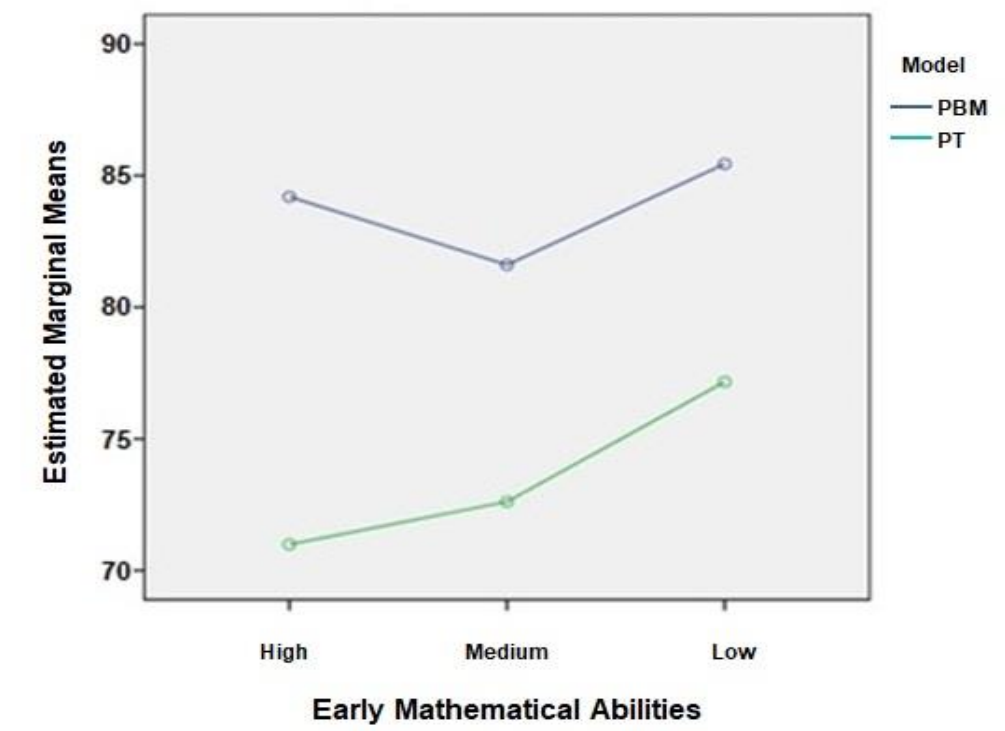

Covariates appearing in the model are evaluated at the Following values: Pre test PBMPT $=62.80$

Figure 2. The Interaction of Learning Models and early mathematical abilities on Students' Mathematical Communication Ability

Interaction between Learning and Students 'Initial Mathematics Ability (High, Medium, Low) on Students' Learning Independence

The interaction referred to in this study is the interaction between learning factors and students' initial abilities towards increasing student learning independence. In the initial ability of students, students are grouped according to high, medium and low abilities. The researchers' findings indicated that there was no significant interaction between the learning model and the students initial mathematical abilities on students' learning independence.

These results can be seen from the results of research where the average gain normalized student learning independence based on guided discovery learning for high (0.41), medium (0.38) and low (0.24) groups. Whereas guided discovery the average gain is normalized for the high $(0.20)$, medium (0.15) and low (0.22) groups. In this case, the students 'initial mathematics ability in problem-based learning with high initial mathematics ability had a greater increase than the students' initial mathematics ability in guided discovery.

To see whether there is an interaction between the learning model and the students 'initial mathematical abilities on students' learning independence. The full ANCOVA test results can be seen in table 4 below. 
Table 4. ANCOVA Analysis Results for the Interaction Between students' initial mathematical abilities and Learning Models on Student Learning Independence

Tests of Between-Subjects Effects

Dependent Variable: Angket_PostTest_PBMPT

\begin{tabular}{|l|r|r|r|r|r|}
\hline Source & $\begin{array}{c}\text { Type III Sum } \\
\text { of Squares }\end{array}$ & df & Mean Square & \multicolumn{1}{c|}{ F } & \multicolumn{1}{c|}{ Sig. } \\
\hline Corrected Model & $1817.134^{\mathrm{a}}$ & 6 & 302.856 & 17.761 & .000 \\
Intercept & 113.396 & 1 & 113.396 & 6.650 & .013 \\
PreTest_PMBPT & 79.657 & 1 & 79.657 & 4.672 & .035 \\
Pembelajaran & 709.261 & 1 & 709.261 & 41.596 & .000 \\
KAM_PBMPT & 130.502 & 2 & 65.251 & 3.027 & .028 \\
Learning * early & 42.327 & 2 & 21.164 & 1.241 & .297 \\
mathematical abilities & 903.716 & 53 & 17.051 & & \\
Error & 376707.000 & 60 & & & \\
Total & 2720.850 & 59 & & & \\
Corrected Total & & & & \\
\hline
\end{tabular}

a. R Squared $=.668($ Adjusted R Squared $=.630)$

obtained $F_{\text {count }}$ factor of learning model * early mathematical abilities is 3.027 while $F_{\text {table }(1,51)}=3,179$ which means $F_{\text {hitung }}<F_{\text {tabel }}$ dan p-value is 0,28 which means greater than 0.05 so that $\mathrm{H}_{0}$ is accepted so that It can be concluded that there is no interaction between the learning model and students' early mathematical abilities on students' learning independence after controlling for students' early abilities

Graphically this interaction can be seen in Figure 3 below:

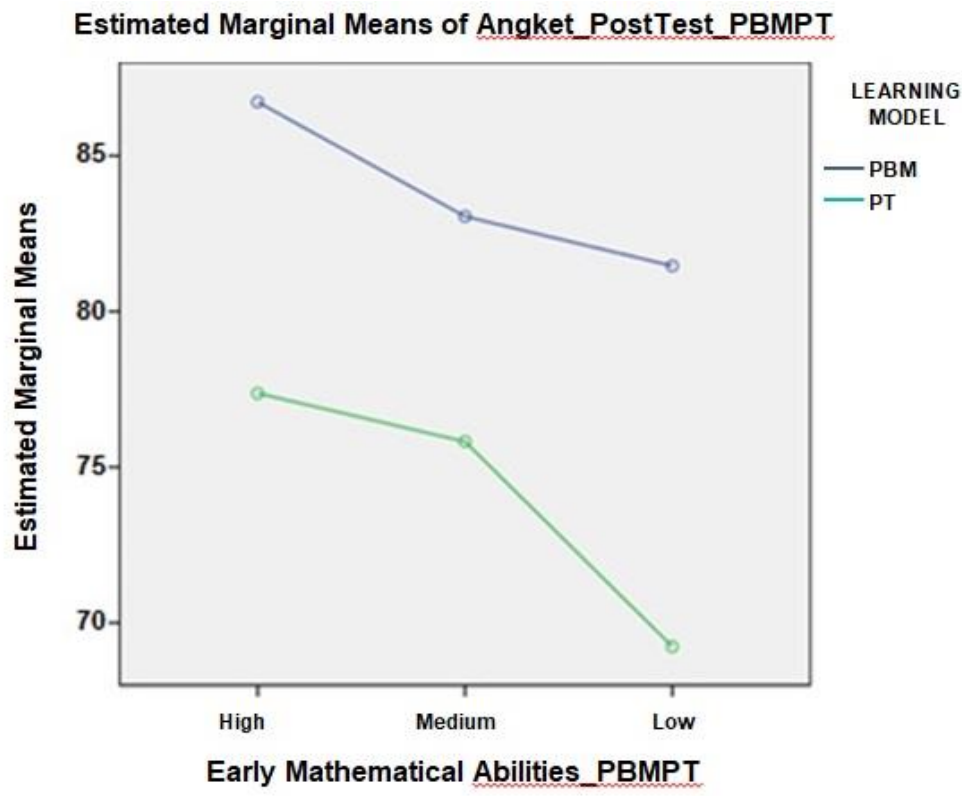

Covariates appearing in the model are evaluated at the Following values: Angket_PreTest_PBMPT $=76.22$

Figure 3. Interaction of Learning Model and students' early mathematical abilities on Student Learning Independence 
Furthermore, the results of the research on student learning independence in the interaction between learning factors and students' initial mathematics abilities can be seen from the ANCOVA test results obtained from the probability value (sig) of 0.28 which is smaller than the probability level (sig) 0.05 . In the study there was no interaction between the learning model and the students' early mathematics skills on students' learning independence.

Theoretically, the interaction occurs as a result of the learning used by the teacher during the teaching and learning process which is able to develop students' abilities in mathematics, not because of the different initial abilities of students. This acceptance could have been due to the grouping of students' initial abilities that did not describe their true abilities, inaccurate sample selection, relatively short research time and there were some students who had permission to go home and did not attend school due to illness, resulting in differences in increased communication skills. in each initial ability (high, medium and low) using problem-based learning models and guided discovery .

When viewed in the field at the time the learning process takes place, the high category of independent learning is more dominant and more profitable in the learning stage. This is because students understand the material being studied more easily, while students with low independence take longer to understand the material and are less active in solving problems together with their groups. This is supported by Hutagalung (2015) research, in which the study used a guided discovery approach and the result was that there was no interaction between learning and the initial mathematics ability to increase students' mathematical understanding abilities.

\section{CONCLUSION}

Based on the analysis of the results and discussion described in this study, several findings were obtained, namely the achievement of predetermined research objectives. As for the conclusions obtained, namely There are differences in the improvement of students' mathematical communication skills taught by problem-based learning models with students who are given guided discovery learning models and then here are differences in the improvement of mathematical learning independence between students who are taught with a problem-based learning model with students who are given a guided discovery learning model.There is no interaction between the learning model and the initial mathematical ability of student's mathematical communication skills and there is no interaction between the learning model and the initial mathematical ability of students' mathematical learning independence.

\section{THANK YOU NOTE}

On this occasion the author would like to express his sincere gratitude and highest appreciation to all those who have helped me, to my husband, parents and family who have supported the author in all matters. Mr. Dr. Elmanani Simamora, M.Si as the first supervisor, Mr. Prof. Dr. Mukhtar, M.Pd as the second supervisor, as well as the head of the Madrasah, as well as the teachers 
and administrative staff of MTsN 3 Labuhanbatu Utara who have given permission and opportunity for the author to conduct research at the school.

\section{REFERENSI}

Adhiawati, M. (2014). Improved mathematical communication skills between students who get the guided discovery approach and students who get the usual approach. Mathematics Education Department Thesis SPs UPI Bandung: unpublished.

Arends, R I. (2012). Learning to Teach ninth edition. New York : McGraw-Hill.

Aminah, S., Wijaya, T. T., \& Yuspriyati, D. (2018). Analisis Kemampuan Komunikasi Matematis Siswa Kelas Viii Pada Materi Himpunan. Jurnal Cendekia: Jurnal Pendidikan Matematika, 2(1), 15-22. https://doi.org/10.31004/cendekia.v2i1.29

Andini, D., Mulyani, N., Wijaya, T., \& Supriyati, D. (2018). Meningkatkan Kemampuan Komunikasi Matematis Dan Self Confidence Siswa Menggunakan Pendekatan PBL Berbantuan Geogebra. Jurnal Derivat: Jurnal Matematika Dan Pendidikan Matematika, 5(1), 82-93.

Ansari, I.B. (2016). Mathematical Communication: Thinking Strategies and Learning Management. Banda Aceh: PeNa

Baroody, A. J. (1993). Problem Solving, Reasoning and Communicating, K-8. Helping Children think Mathematically. New York: Merril, an inprint of Macmillan Publishing, Company

Barrows, Howard S., \& Tamblyn, Robyn M. (1980). Problem Based Learning An Approach to Medical Education. New York: Springer Publishing Company.

Bishop. (1988). Mathematics Education in Its Cultural Context.

Dewey, John. (1964). Democracy and Education. New York: The Macmillan Company.

Dini, M., Wijaya, T. T., \& Sugandi, A. I. (2018). Pengaruh Self Confidence Terhadap Kemampuan Pemahaman Matematik Siswa Smp. Jurnal Silogisme, 3(1), 1-7.

Effendi, L. A. (2012). Learning Mathematics with the Guided Discovery Method to Improve the Representation and Problem Solving skills of Junior High School Students. LPPM UPI. Journal of Educational Research, Vol. 13, No. 2, ISSN 1412-565X

Greenes, C. \& Schulman, L. (1996). Communication Processes in Mathematics Explorations and Investiations. In P. C. Elliot and M. J. Kenney (Eds). 1996. Yearbook. Communication in Mathematics, K-12 and Beyond. USA: NCTM

Hutagalung, Yusnarti.(2015). Improved Representation Ability and Learning Independence of Junior High School Students Through Guided Discovery Approach with Autograph Assistance. Thesis. Medan: Mathematics Education UNIMED Medan.

Kadir. (2015). Applied Statistics: Concepts, Examples and Data Analysis with the SPSS / Lisrel Program in Research. Jakarta: PT. Rajagrafindo Persada.

Kuhlthau, C. C. (2007). Guided Inqury: Learning in The $21^{\text {st }}$ Century School. Wesport, CT : Libraries Unlimited. 
Kulsum, S. I., Hidayat, W., Wijaya, T. T., \& Kumala, J. (2019). Analysis on high school students' mathematical creative thinking skills on the topic of sets. Jurnal Cendekia : Jurnal Pendidikan Matematika, 03(02), 431-436. https://doi.org/https://doi.org/10.31004/cendekia.v3i2

Marbun, S.R. (2019). Differences in the Increased Ability of Understanding Mathematical Concepts and Student Motivation with Guided Discovery Approach with Geogebra Software and Direct Learning Model in MTs Negeri Barus. Unimed Mamatika Education Thesis: Unpublished.

Minarni, A. (2013).The effect of problem-based learning on the mathematical understanding and social skills of students of State Junior High Schools in Bandung. Journal of Paradigma Education.Vol 6 Number 2, hal 162-174. DOI: https://doi.org/10.24114/paradikma.v6i2.1077

Minarni, A., Napitupulu, E., \& Husein, R. (2016). Mathematical Understanding and Representation Ability of Public Junior High School in North Sumatra. Journal on Mathematics Education. Vol 7, No. 1, January 2016, pp. 45-58. DOI : http://dx.doi.org/10.22342/jme.7.1.2816.43-56

Mulbar, Usman. (2008). Student Metacognition in Solving Mathematical Problems. (Online).

NCTM. (2003). Standards for Secondary Mathematics Teacher. United States of America : The National Council of Teachers of Mathematics, Inc.

Russeffendi. (2005). Basics of Educational Research and Other Non-exact Fields. Bandung: Tarsito.

Sanjaya. W. (2008). Educational Process Standards Oriented Learning Strategy. Predana Media Grup: Bandung

Saragih, Sahat and Elvis,Napitupulu. (2015). Developing Student-Centered Learning Model to Improve High Order Mathematical Thinking Ability. International Education Studies; Vol. 8, No. 6. Published by Canadian Center of Science and Education. DOI: 10.5539 / ies.v8n6p104

Sugiyono. (2012). Qualitative and Quantitative Research Methods R \& D. Bandung: Alfabeta

Tan, S., Zou, L., Wijaya, T. T., Suci, N., \& Dewi, S. (2020). Improving student creative thinking ability with problem based learning approach using hawgent. Journal on Education, 02(04), 303-312.

Widarto., Pardjono., And Widodo, N. (2012). Development of Soft Skill and Hard Skill Learning Models for Vocational School Students. Cakrawala Pendidikan, Th. XXXI, No. 3: 409-423. DOI: https://doi.org/10.21831/cp.v0i3.1139

Wijaya, T. T., Ying, Z., Chotimah, S., Bernard, M., Zulfah, \& Astuti. (2020). Hawgent dynamic mathematic software as mathematics learning media for teaching quadratic functions. Journal of Physics: Conference Series, 1592(1). https://doi.org/10.1088/1742-6596/1592/1/012079

Wijaya, T. T., Ying, Z., Cunhua, L., \& Zulfah. (2020). Using vba learning media to improve students ' mathematical understanding ability. Journal On Education, 02(02), 245-254.

Zhang, L., Zhou, Y., \& Wijaya, T. T. (2020). Hawgent dynamic mathematics software to improve problem-solving ability in teaching triangles. Journal of Physics: Conference Series, 1663(1). https://doi.org/10.1088/1742-6596/1663/1/012069 
Zimmerman, B.J and Martinez-Pons.(1990).’'Student Differences in Self-regulated Learning: Relating Grade, Sex, and Giftedness to Self-efficacy and Strategy Use 